\title{
DISTRIBUTION AND ABUNDANCE OF MAJOR ZOOPLANKTON GROUPS IN AMBON BAY (MALUKU, INDONESIA) DURING A SALP SWARMING, WITH NOTES ON CHAETOGNATHA AND PTEROPODA SPECIES
}

\author{
by \\ Dick G. Troost ${ }^{1}$ ), A. B. Sutomo ${ }^{2}$ ) and L. F. Wenno ${ }^{2}$ )
}

(Manuscript received 6 March 1975)

\begin{abstract}
Eight zooplankton samples from several stations along a line from the inner to the outermost part of Ambon Bay were studied. In the samples from the Inner Bay, the salp Thalia sibogae SoEST outnumbers all other groups. The competition for food is responsible for relatively low numbers of these groups. At the Outer Bay stations the Copepoda is by far the most abundant group.

Graphs indicating the numbers of specimens per $\mathrm{m}^{3}$ of each of the seventeen groups are given for three groups of stations, of which the central one appeared to be the richest.

The Chaetognatha, Pteropoda, and oblong fish eggs were identified. Oxygen and reactive phosphorus are presumed to be more connected with differences in planktonic life in Ambon Bay than temperature and salinity.

Because of the importance of the live-bait fishery, and the threat of increasing pollution, a call is made for more extensive surveys.
\end{abstract}

\section{IKHTISAR}

Delapan contoh zooplankton dari beberapa stasion yang terletak sepanjang garis di dalam dan diluar Teluk Ambon dipelajari. Dalam contoh plankton yang diambil dari teluk bagian dalam, Thalia sibogae Soest terdapat dalam jumlah yang melebihi jumlah kelompok lain secara keseluruhan. Persaingan untuk mendapatkan makanan merupakan penyebab rendahnya jumlah zooplankton lainnya. Sedangkan pada stasion di luar teluk, Copepoda merupakan zooplankton yang terbanyak.

Jumlah spesimen per $\mathrm{m}^{3}$ untuk 17 kelompok zooplankton yang didapatkan dari tiga kelompok stasion ditunjukkan dalam grafik. Kelompok station yang di tengah mengandung zooplankton yang terkaya.

Chaetognatha, Pteropoda dan telur ikan yang berbentuk lonjong telah diidentifikasikan.

1) UNESCO Regional Office for Science and Technology for Southeast Asia, Jakarta.

2) Ambon Research Station, Lembaga Oseanologi Nasional (LIPI), Ambon. 


\section{G. Troost et al.}

Oksigen dan phosphor reaktip diduga mempunyai hubungan yang lebih erat dengan kehidupan planktonik di Teluk Ambon daripada dengan pengaruh suhu dan kadar garam.

Oleh karena sangat pentingnya perikanan ikan umpan serta semakin meningkatnya pencemaran, maka disarankan agar diadakan penelitian yang lebih mendalam.

\section{INTRODUCTION}

Studies on the plankton and hydrography of the Ambon Bay, Maluku, were initiated in February 1973 at the Ambon Research Station of the National Institute of Oceanology, Indonesian Institute of Sciences. Samplings by using plankton nets and Nansen bottles were made for three days each month at eight stations in the bay. The bay consists of two parts, a larger outer part and a smaller inner part, called Outer

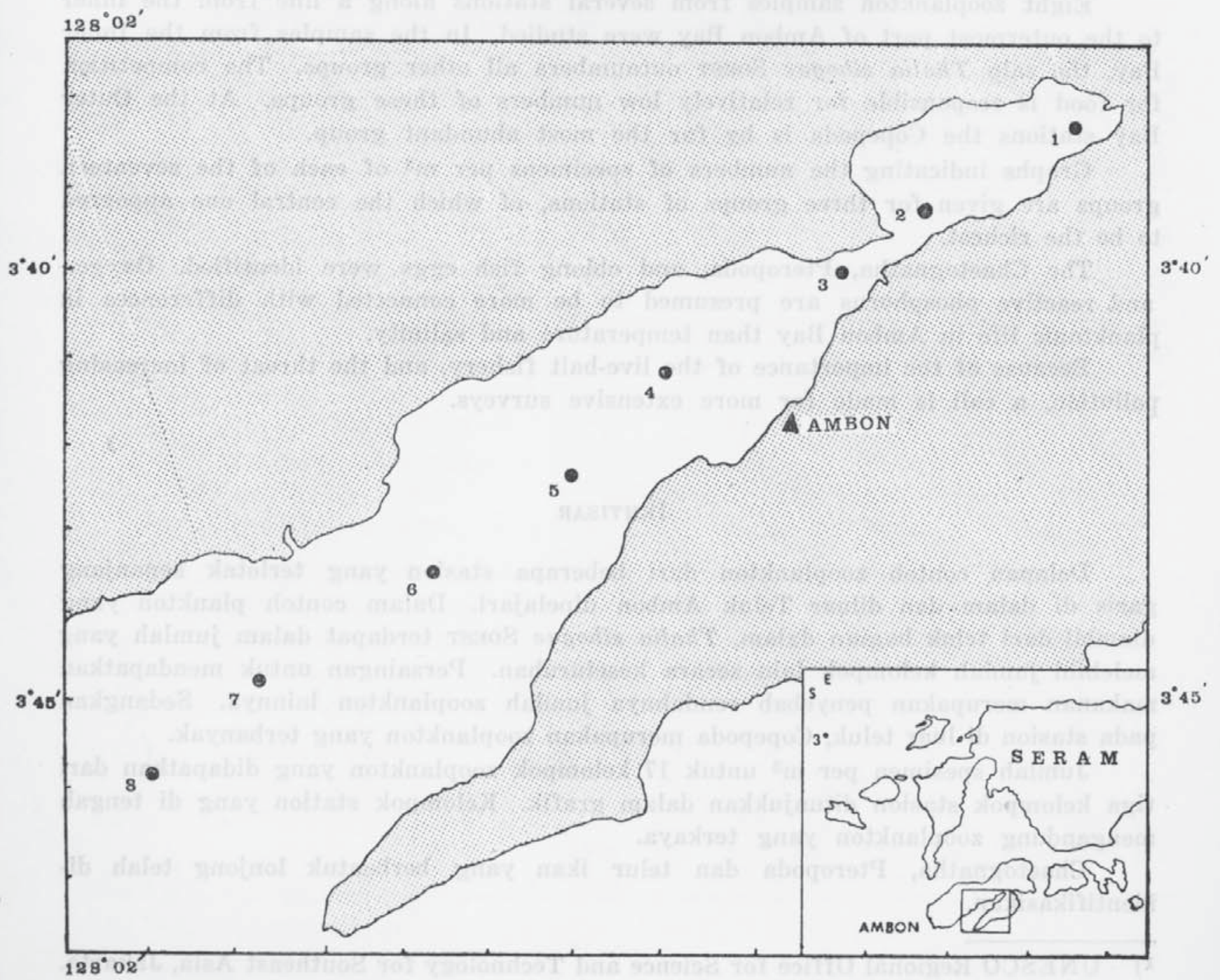

Figure 1. The location of the stations in the Bay of Ambon. 
DISTRIBUTION OF ZOOPLANKTON IN AMBON BAY

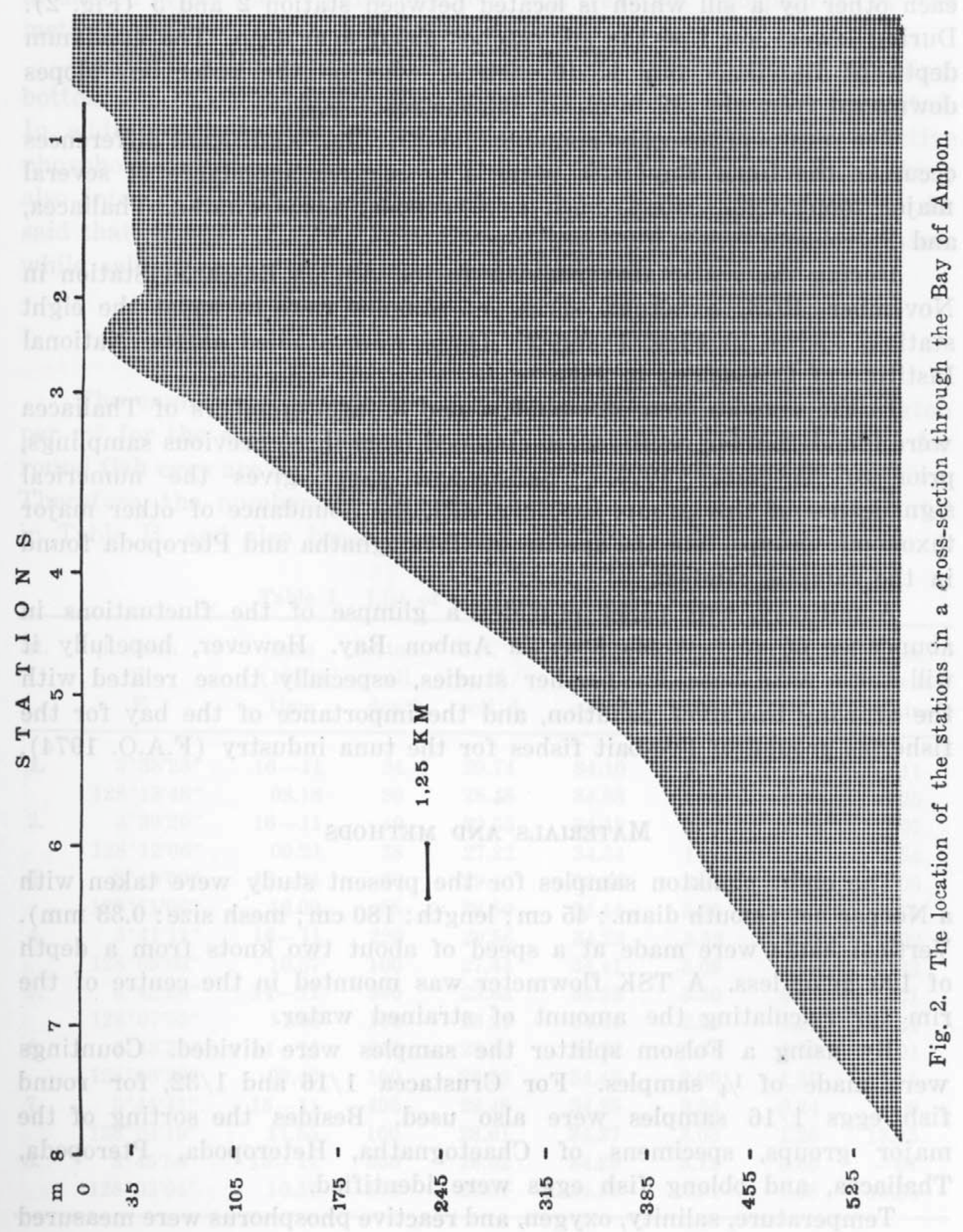




\section{G. Troost et al.}

and Inner Bay respectively (Fig. 1). These parts are separated from each other by a sill which is located between station 2 and 3 (Fig. 2). During lowest low tide the sill reaches about $9 \mathrm{~m}$ deep. The maximum depth of the inner bay is 40 metres, whereas the outer bay slopes downward from the sill to about 800 metres.

The results of monthly samplings indicate that significant differences occur in the Inner Bay with regards to relative abundance of several major zooplankton groups such as Copepoda, Chaetognatha, Thaliacea, and Polychaeta.

During the senior author's visit to the Ambon Research Station in November 1973, a second series of samples were taken at the eight stations shown in Figs. 1 and 2. These were studied at the National Institute of Oceanology in Jakarta.

In the samples from station 1, 2 and 3, large numbers of Thaliacea were found. Similar results were obtained from three previous samplings, prior to November 1973. The present paper gives the numerical significance of this group, together with the abundance of other major taxonomic groups, and the species of Chaetognatha and Pteropoda found in the samples studied.

Admittedly, this paper provides a glimpse of the fluctuations in abundance of various plankton in Ambon Bay. However, hopefully it will serve as a base for further studies, especially those related with the growing threat of pollution, and the importance of the bay for the fisheries ground of live-bait fishes for the tuna industry (F.A.O. 1974).

\section{MATERIALS AND METHODS}

The eight plankton samples for the present study were taken with a Norpac net (mouth diam.: $45 \mathrm{~cm}$; length: $180 \mathrm{~cm}$; mesh size: $0.33 \mathrm{~mm}$ ). Vertical hauls were made at a speed of about two knots from a depth of $100 \mathrm{~m}$ or less. A TSK flowmeter was mounted in the centre of the rim for calculating the amount of strained water.

By using a Folsom splitter the samples were divided. Countings were made of $1 / 4$ samples. For Crustacea $1 / 16$ and $1 / 32$, for round fish eggs 1/16 samples were also used. Besides the sorting of the major groups, specimens of Chaetognatha, Heteropoda, Pteropoda, Thaliacea, and oblong fish eggs were identified.

Temperature, salinity, oxygen, and reactive phosphorus were measured at different depths at each station just prior to plankton sampling. For temperature observation, thermometers were fixed to the Nansen 


\section{DISTRIBUTION OF ZOOPLANKTON IN AMBON BAY}

bottles; for salinity, a conductive salinometer was used; oxygen was measured with the Winkler method; and reactive phosphorus by the method of STRICKLAND \& PARSONS (1968).

In Table I, the position of the stations, date and time ${ }^{1}$ ) of sampling, bottom and collecting depths, tide ${ }^{2}$ ) and $\mathrm{m}^{3}$ water strained are presented. In addition, the values of temperature, salinity, oxygen, and reactive phosphorus at the surface and collecting depth are indicated. Taking also into account the measurements at intermediate depths it can be said that, except for a few anomalies, temperature and oxygen decreased, while salinity and reactive phosphorus increased with added depth.

\section{RESULTS}

The number of specimens for the major groups of zooplankton per $\mathrm{m}^{3}$ for the eight stations are given in Table II. Numbers given for round fish eggs are questionable because of losses during sample handling. Therefore, the numbers of fish eggs have been deleted from the total in Table II, and also because no egg data were taken from station 4 .

Table I. List of stations in Ambon Bay.

\begin{tabular}{|c|c|c|c|c|c|c|c|c|}
\hline st. & $\begin{array}{c}\text { position } \\
\text { S } \\
\text { E }\end{array}$ & $\begin{array}{l}\text { date } \\
(1973) / \\
\text { time }\end{array}$ & $\begin{array}{c}\text { bottom/ } \\
\text { coll. } \\
\text { depth }\end{array}$ & $\begin{array}{l}\mathrm{T}\left(\mathrm{C}^{\circ}\right) \\
\text { surf./ } \\
\text { coll. d. }\end{array}$ & $\begin{array}{c}\mathrm{S}\left(\% \%_{00}\right) \\
\text { surf./ } \\
\text { coll. d. }\end{array}$ & $\begin{array}{c}\mathrm{O}(\mathrm{ml} / \mathrm{l}) \\
\text { surf./ } \\
\text { coll. d. }\end{array}$ & $\begin{array}{c}\text { P (jgat/1) } \\
\text { surf./ } \\
\text { coll. d. }\end{array}$ & $\begin{array}{c}\text { tide/ } \\
\mathrm{m}^{3} \text { water } \\
\text { strained }\end{array}$ \\
\hline \multirow[t]{2}{*}{1.} & $3^{\circ} 38^{\prime} 23^{\prime \prime}$ & $16-11$ & 24 & 29.74 & 34.10 & 3.17 & 0.18 & 11 \\
\hline & $128^{\circ} 13^{\prime} 48^{\prime \prime}$ & 08.18 & 20 & 28.48 & 34.38 & 2.60 & 0.50 & 2.25 \\
\hline \multirow[t]{2}{*}{2.} & $3^{\circ} 39^{\prime} 20^{\prime \prime}$ & $16-11$ & 40 & 29.35 & 34.19 & 3.34 & 0.19 & 07 \\
\hline & $128^{\circ} 12^{\prime} 06^{\prime \prime}$ & 09.21 & 38 & 27.22 & 34.34 & 1.76 & 1.51 & 4.54 \\
\hline \multirow[t]{2}{*}{3.} & $3^{\circ} 40^{\prime} 00^{\prime \prime}$ & $16-11$ & 60 & 29.40 & 33.66 & 3.48 & 0.38 & 05 \\
\hline & $128^{\circ} 11^{\prime} 06^{\prime \prime}$ & 10.00 & 55 & 28.80 & 34.44 & 3.25 & 0.87 & 6.64 \\
\hline \multirow[t]{2}{*}{4.} & $3^{\circ} 41^{\prime} 11^{\prime \prime}$ & $16-11$ & 220 & 29.56 & 34.22 & 3.52 & 0.54 & 02 \\
\hline & $128^{\circ} 09^{\prime} 03^{\prime \prime}$ & 10.57 & 100 & 27.44 & 34.41 & 3.08 & 1.08 & 11.33 \\
\hline \multirow[t]{2}{*}{5.} & $3^{\circ} 42^{\prime} 20^{\prime \prime}$ & $14-11$ & 340 & 29.63 & 34.22 & 3.30 & 0.67 & -01 \\
\hline & $128^{\circ} 07^{\prime} 53^{\prime \prime}$ & 11.05 & 100 & 28.21 & 34.40 & 2.95 & 1.25 & 11.31 \\
\hline \multirow[t]{2}{*}{6.} & $3^{\circ} 43^{\prime} 30^{\prime \prime}$ & $14-11$ & 415 & 28.93 & 34.32 & 3.39 & 0.52 & 01 \\
\hline & $128^{\circ} 06^{\prime} 20^{\prime \prime}$ & 09.40 & 100 & 28.53 & 34.43 & 2.90 & 1.35 & 11.11 \\
\hline \multirow[t]{2}{*}{7.} & $3^{\circ} 44^{\prime} 41^{\prime \prime}$ & $15-11$ & 495 & 29.48 & 34.25 & 3.34 & 0.34 & 00 \\
\hline & $128^{\circ} 04^{\prime} 19^{\prime \prime}$ & 11.55 & 100 & 28.61 & 34.37 & 3.03 & 1.20 & 13.85 \\
\hline \multirow[t]{2}{*}{8.} & $3^{\circ} 45^{\prime} 50^{\prime \prime}$ & $15-11$ & 560 & 29.02 & 34.29 & 3.12 & 0.60 & -01 \\
\hline & $128^{\circ} 03^{\prime} 04^{\prime \prime}$ & 10.37 & 100 & 28.57 & 34.39 & 2.81 & 1.28 & 13.85 \\
\hline
\end{tabular}

1) time given in East Indonesian Time.

2) tide in number of decimeters above ( - if below) mean sea level (Hidpal 1974). 
The samples from stations $1-4$ were taken on the same day but at different times, while stations $5-8$ were sampled during the preceding two days (Table I). As a consequence, tides were different during sampling. To allow, at least partially, for the tidal excursion of the animals, the numbers per $\mathrm{m}^{3}$ of the different groups for each station are not considered separately. Instead, average numbers are taken for the following three groups of stations: 1,$2 ; 3,4,5 ; 6,7,8$. These average numbers are given in the form of graphs (Fig. 3). Fig. 3a shows conspicuous difference between the two most abundant groups in the Inner and Outer Bay, i.e. Thaliacea and Copepoda respectively. The first group was represented by one species only i.e. Thalia sibogae SoEST. If the numbers for these two groups are expressed as percentages of the total number of zooplankton specimens found per $\mathrm{m}^{3}$ at the three station groups, the following figures are obtained:
Copepoda
St. 1,2
St. $3,4,5$
St. $6,7,8$
Thatia sibogae
$30.9 \%$
$80.5 \%$
$84.9 \%$
$53.8 \%$
$4.6 \%$
$0.16 \%$

The other groups account for only about $15 \%$.

Table II. Number of specimens per $\mathrm{m}^{3}$.

\begin{tabular}{|c|c|c|c|c|c|c|c|c|}
\hline stations & 1 & 2 & 3 & 4 & 5 & 6 & 7 & 8 \\
\hline Siphonophora & 0 & 3.5 & 65 & 36 & 47 & 39 & 21 & 24 \\
\hline other Medusae & 45 & 21 & 3.6 & 2.5 & 0 & 4.0 & 4.9 & 1.7 \\
\hline Ctenophora & 1.8 & 2.6 & 1.2 & 0.4 & 0 & 0 & 0 & 0 \\
\hline Polychaeta & 0 & 0 & 11 & 0 & 3.9 & 5.0 & 4.9 & 2.0 \\
\hline Chaetognatha & 34 & 48 & 79 & 44 & 73 & 95 & 43 & 47 \\
\hline Copepoda & 338 & 174 & 2072 & 1098 & 1712 & 1164 & 1044 & 945 \\
\hline other Crustacea & 62 & 32 & 193 & 49 & 31 & 23 & 12 & 21 \\
\hline Heteropoda & 0 & 0 & 5.4 & 5.3 & 3.5 & 4.3 & 1.7 & 2.0 \\
\hline Pteropoda & 0 & 0 & 12 & 6.7 & 7.1 & 10 & 5.8 & 5.8 \\
\hline other Mollusca & 0 & 0 & 14 & 19 & 14 & 19 & 12 & 9.0 \\
\hline Appendicularia & 0 & 0 & 57 & 29 & 76 & 58 & 42 & 29 \\
\hline Thaliacea (sol.) & 50 & 23 & 17 & 0 & 0 & 0 & 0 & 0 \\
\hline Thaliacea (aggr.) & 484 & 339 & 260 & 0.4 & 0.7 & 6.1 & 0 & 0 \\
\hline Doliolidae & 0 & 0 & 0 & 0.7 & 2.1 & 1.4 & 1.4 & 1.4 \\
\hline (Fish eggs, round & 71 & 7.0 & 88 & - & 62 & 121 & 97 & 129) \\
\hline (Fish eggs, oblong & 1.8 & 4.4 & 9.0 & - & 2.1 & 3.6 & 0 & $0.6)$ \\
\hline Fish larvae & 3.6 & 0 & 11 & 0.7 & 0 & 1.1 & 0 & 0.6 \\
\hline total & 1018 & 643 & 2801 & 1292 & 1970 & 1430 & 1193 & 1088 \\
\hline
\end{tabular}




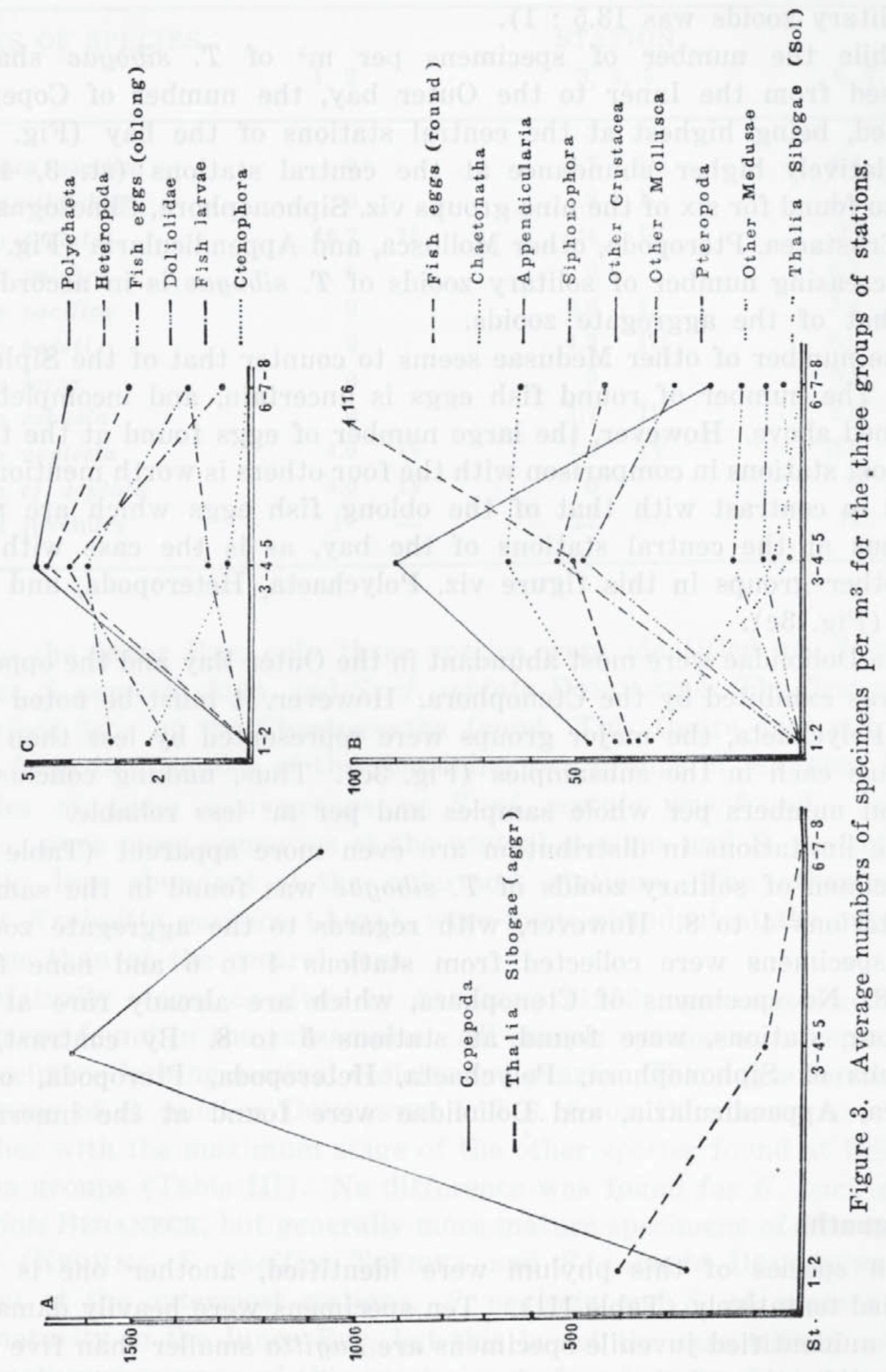




\section{G. Troost et al.}

Before sampling, most of the aggregate zooids of $T$. sibogae are arranged in chains (the average ratio between numbers of aggregate and solitary zooids was $13.5: 1$ ).

While the number of specimens per $\mathrm{m}^{3}$ of $T$. sibogae sharply decreased from the Inner to the Outer bay, the number of Copepoda increased, being highest at the central stations of the bay (Fig. 3a). The relatively higher abundance at the central stations (st. 3, 4, 5) was also found for six of the nine groups viz. Siphonophora, Chaetognatha, other Crustacea, Pteropoda, other Mollusca, and Appendicularia (Fig. 3b). The decreasing number of solitary zooids of $T$. sibogae is in accordance with that of the aggregate zooids.

The number of other Medusae seems to counter that of the Siphonophora. The number of round fish eggs is uncertain, and incomplete as mentioned above. However, the large number of eggs found at the three outermost stations in comparison with the four others is worth mentioning. This is in contrast with that of the oblong fish eggs which are most numerous at the central stations of the bay, as is the case with the three other groups in this figure viz. Polychaeta, Heteropoda, and fish larvae (Fig. 3c).

The Doliolidae were most abundant in the Outer Bay and the opposite trend was exhibited by the Ctenophora. However, it must be noted that except Polychaeta, the major groups were represented by less than five specimens each in the subsamples (Fig. 3c). Thus, making conclusions based on numbers per whole samples and per $\mathrm{m}^{3}$ less reliable.

The limitations in distribution are even more apparent (Table II). No specimen of solitary zooids of $T$. sibogae was found in the samples from stations 4 to 8 . However, with regards to the aggregate zooids, a few specimens were collected from stations 4 to 6 and none from 7 and 8. No specimens of Ctenophora, which are already rare at the first four stations, were found at stations 5 to 8 . By contrast, no specimens of Siphonophora, Polychaeta, Heteropoda, Pteropoda, other Mollusca, Appendicularia, and Doliolidae were found at the innermost station.

\section{Chaetognatha}

Ten species of this phylum were identified, another one is only identified tentatively (Table III). Ten specimens were heavily damaged. All the unidentified juvenile specimens are Sagitta smaller than five mm. The identification of these specimens to species was impossible because of their poor state of preservation and small size. 


\section{DISTRIBUTION OF ZOOPLANKTON IN AMBON BAY}

Table III. Number of Chaetognatha specimens per $\mathrm{m}^{3}$ and their observed maximum stage of maturity

\begin{tabular}{lrrrrrl}
\hline NAMES OF SPECIES & \multicolumn{7}{c}{ STATION } \\
& 1,2 & $3,4,5$ & $6,7,8$ \\
\hline Krohnitta pacifica & 0 & & 5.7 & III & 4.2 & II \\
Pterosagitta draco & 0 & & 1.8 & I & 4.2 & IV \\
Sagitta enflata & 16.7 & II & 24 & IV & 22 & IV \\
Sagitta pulchra & 0 & & 0 & & 0.2 & II \\
Sagitta pacifica & 0 & & 0.6 & I & 3.4 & II \\
Sagitta bedoti & 0 & & 0 & & 8.0 & III \\
Sagitta ferox & 0 & & 1.7 & II & 0.2 & I, III \\
Sagitta robusta & 0 & & 4.6 & IV & 3.6 & III \\
Sagitta neglecta & 4.6 & IV & 0 & & 0 & III \\
Sagitta cf. septata & 4.0 & IV & 22 & - & 12 & - \\
Sagitta juveniles & 17 & - & & & & \\
\hline
\end{tabular}

In the Inner Bay, only three species were identified i.e. $S$. enflata Grassi, S. neglecta AIDA, and S. cf. septata DonCaster. The first species comprised $38 \%$ of the Chaetognatha found. This figure does not differ much from the samples of the remaining two groups of stations. In the samples of these two groups no $S$. cf. septata was found. Juvenile Sagite were more numerous at the central stations and $S$. neglecta was slightly less abundant at the outermost stations. The other species, except Krohnitta pacifica (AIDA), were more abundant at the outermost stations than at the central ones.

Maturity stages as given by ALVARINo (1963) were assessed for all specimens found in the subsamples. All sample species were represented by specimens lacking seminal vesicles and ovaries. The stages for the four specimens of $S$. pulchra DONCASTER and $S$. ferox DONCASTER are listed, together with the maximum stage of the other species found at the three station groups (Table III). No difference was found for K. pacifica and $S$. bedoti BeRANECK, but generally more mature specimens of Pterosagitta draco (KROHN), S. pacifica TOKIOKA and S. robusta DoNCASTER were present at the outermost stations. S. neglecta and $S$. cf. septata reach full maturity in the Inner Bay, but this is not the case with $S$. enflata. Full mature specimens of this species were found in the first and second maturity cycles only. No representatives in the third cycle were present. 


\section{G. Troost et al.}

The development of the ovaries in comparison with that of the seminal vesicles (ALVARINo 1963) varies in the specimens of $S$. pacifica, S. bedoti, $S$. robusta, and $S$. neglecta. In these species the development of the ovaries lags one or two "maturity stages" behind that of the seminal vesicles.

\section{Mollusca}

No Mollusca were found in the subsamples from the Inner Bay stations, but they were represented in the Outer Bay (Table II). Other Mollusca was the most abundant group followed by Pteropoda and Heteropoda. About $90 \%$ of the Heteropoda comprised specimens of the genus Atlanta. Some of the remaining specimens were identifiable as Firoloida kowalewsky VAYssiere, but because of their poor condition, the others can only be identified to the family level (i.e. Pterotracheidae).

Only seven specimens of Gymnosomata were found among the specimens of Pteropoda. Three are Hydromyles globulosa (RANG) which were reported by TESCH (1950) as being extraordinarily abundant in the tropical Indo-Pacific. The other four are Paraclione pelseneeri $\mathrm{TESCH}$, Gleba chrysostricta (Troschel), and two juveniles of the genera Pneumoderma and Pneumodermopsis.

Generally most of the Pteropoda collected were Thecosomata belonging to Limacina trochiformis (ORBIGNY), Creseis acicula (RANG), Creseis virgula (RANG), Hyalocylis striata (RANG), Diacria quadridentata (DE Blainville), Cavolinia longirostris (De Blainville) and Desmopterus papilio CHUN. Although the calcareous part of the Euthecosomata is poorly preserved, some formae could be distinguished, i.e. C. acicula forma acicula (RANG), C. virgula forma conica Eschscholtz and C. longirostris forma angulosa Eydoux \& Souleyet. All Pteropoda species and formae were present at the central as well as at the outermost stations, while the numbers per $\mathrm{m}^{3}$ were more or less the same.

The category of other Mollusca consisted of $90 \%$ Prosobranchiata larvae and $10 \%$ Lamellibranchiata larvae.

\section{Fish eggs}

Only the oblong fish eggs are considered here. They are identified as Stolephorus eggs as they agree closely with those described by DELSMAN (1931). The absence of a knob on the egg-membrane and an oil-globule indicate that these eggs belong to $S$. zollingeri BLEEKER. According to the Ambon Research Station's quarterly reports, this species frequently comprises the bulk of live-bait fishes caught at night with a beach seine near Poka (Fig. 1). 


\section{DISTRIBUTION OF ZOOPLANKTON IN AMBON BAY}

\section{Discussion}

The swarming of different species of salps, in temperate as well as in tropical zones, has been recorded by FrASER $(1961,1962)$, WICKSTEAD (1958), Heron (1972), and others. Concerning Thalia sibogae, SoEsT (1973) suggested a possible preference for neritic surroundings, a supposition supported by the results of our Inner Bay samplings. Correlation of the swarming of this salp with lunar phases, salinity, or temperature cannot be determined from the present available data. Sampling at more frequent intervals than once per month is apparently required to ascertain such associations.

The value of salps as a source of fish food is doubtful. In fact, their presence may have a negative effect, because of the depletion of food or metabolic products (Fraser 1961). However, one sample of bait fishes taken by the Ambon Research Station (9/10 November 1973) during a night beach seine, contained enormous numbers of Thalia sibogae in addition to a large catch of anchovies (Stolephorus zollingeri). Moreover, F.A.O. (1974) mentioned that during 1971 the beach-seine fisheries in Inner Ambon Bay supplied a substantial portion of the bait-size fishes caught in the Ambon area, comprising about $90 \%$ of the live-bait fish for the skipjack fisheries. Therefore, the harmful effects of the swarming of this salp on live-bait fishes are doubtful.

At the Inner Bay (stations 1 and 2) much less Copepoda were found then at the outer Bay (stations $3-8$ ). This is understandable when the predominance of salps in the Inner Bay is considered. Salps are herbivorous, filtering out phytoplankton, and therefore leaving less food available for other herbivorous animals such as Copepoda. This depletion of food may, in turn, also affect carnivorous species (FrASER 1961). These facts may account for the lack of Siphonophora (except a few at st. 2), Polychaeta, Heteropoda, Pteropoda, other Mollusca, and Appendicularia at the Inner Bay stations in contrast to their presence in the Outer Bay.

Difference in physical and composition characteristics of the water masses in the Inner and Outer Bay may likewise be responsible for the uneven distribution of organisms, as well as for the swarming of salps. The values for various parameters given in Table IV are calculated from figures in the quarterly reports of the Ambon Research Station. In reading these figures it should be taken into account that the collecting depths were $20 \mathrm{~m}, 35 \mathrm{~m}$, and $100 \mathrm{~m}$ at stations 1,2 , and the Outer Bay respectively. From this table it is apparent that temperature and salinity 


\section{G. Troost et al.}

do not differ much in Inner and Outer Bay. The greater influence of the rainy season (April - August) is responsible for the somewhat lower salinity values at the surface of the Inner Bay as compared with the Outer Bay.

Substantial differences were found between the two parts of the bay with regards to oxygen and reactive phosphorus, especially when the difference in collecting depths is taken into account. Mean and lowest oxygen values at $20 \mathrm{~m}$ and $35 \mathrm{~m}$ in the Inner Bay were much lower than at $100 \mathrm{~m}$ depth in the Outer Bay. While the mean reactive phosphorus value did not differ, the minimum and maximum values at collecting depths $(20 \mathrm{~m}$ and $35 \mathrm{~m})$ in the Inner Bay were respectively lower and higher as compared with the values at $100 \mathrm{~m}$ in the Outer Bay.

Thus, it appears that temperature and salinity are less connected with the fluctuations in abundance of planktonic organisms in the Ambon Bay than oxygen and reactive phosphorus.

An additional point of interest concerns with grab samples taken from the bottom of the Inner Bay since October 1974 when sedimentation studies were initiated. According to quarterly reports of the Ambon Station most of these samples, especially those from the deepest part, were characterized by strong odour of $\mathrm{H}_{2} \mathrm{~S}$. This can be explained on the basis of the bottom profile of the bay (Fig. 2).

The shallow sill decreases the mixing action of the deepest water with the surface water in the Inner Bay. The former has a higher salinity and lower temperature (Tables I and IV). Therefore, decaying organisms, especially after a plankton bloom, can consume all the oxygen present in the deeper water and give rise to sulphate-reducing bacteria.

Strong winds, tidal currents, and seiches may interrupt this pattern, causing nutrient rich deeper water to mix with the surface layer, especially in the region above the sill. This may account for the relatively high numbers of specimens of several groups found at the central stations (Table II and Fig. 3). These samples were taken during ebb-tide (Table I).

In addition, more extensive surveys are necessary to confirm the above observations and the preliminary conclusions presented herein. Studies of this nature are important as they have a direct bearing on the economics of the live-bait fishery of the Ambon Bay.

Comparing the enthusiastic description of Ambon Bay given by WALLACE (1962) with the present situation, we realize that profound changes have occured during the past century. Siltation resulting from improper land use and other forms of pollution have taken a heavy toll 


\section{DISTRIBUTION OF ZOOPLANKTON IN AMBON BAY}

Table IV. Mean values and their ranges of certain characteristics of the water at the surface and at collecting depth (coll. d.) in the Inner and Outer Ambon Bay (measurements done once a month from June 1973 - August 1974).

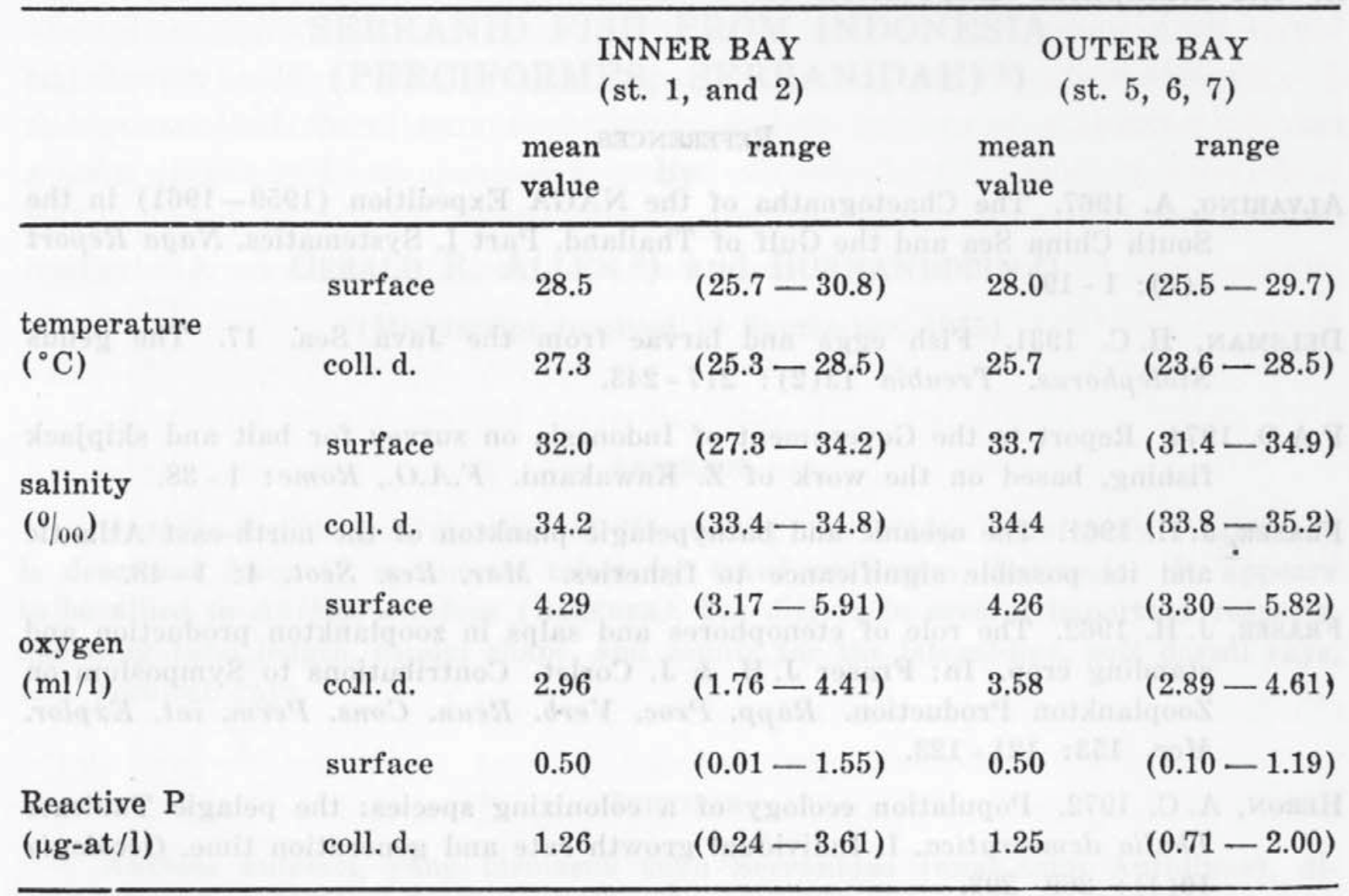

in the bay which WALLACE (1962) described in the glowing terms which follow: "There is perhaps no spot in the world richer in marine productions, corals, shells and fishes, than the harbour of Amboyna".

In view of the changes which have occured since Wallace's time coupled with the threat of increasing pollution, studies of the planktonic composition of the bay and the environmental factors which regulate the composition are indispensible. Only in this way can any sudden or long-range fluctuation of the natural populations of plankton be properly evaluated.

\section{ACKNOWLEDGEMENTS}

We are very grateful to Dr. ApRILANi SoEgIarto, Director of the National Institute of Oceanology, for providing working facilities for the senior author at the Jakarta laboratory.

The gymnosomatous Pteropoda were kindly identified by Dr. S. VAN DER SPOEL of the Institute of Taxonomic Zoology, Amsterdam. 
We are indebted to Gerald R. Allen of the Western Australian Museum for critically reading the manuscript during his participation in the Rumphius Expedition II.

\section{REFERENCES}

Alvarino, A. 1967. The Chaetognatha of the NAGA Expedition (1959-1961) in the South China Sea and the Gulf of Thailand. Part I. Systematics. Naga Report $4(2): 1-197$.

Delsman, H.C. 1931. Fish eggs and larvae from the Java Sea. 17. The genus Stolephorus. Treubia 13(2): 217-243.

F.A.O. 1974. Report to the Government of Indonesia on survey for bait and skipjack fishing, based on the work of Z. Kawakami. F.A.O., Rome: 1-38.

Fraser, J.H. 1961. The oceanic and bathypelagic plankton of the north-east Atlantic and its possible significance to fisheries. Mar. Res. Scot. 4: 1-48.

Fraser, J. H. 1962. The role of ctenophores and salps in zooplankton production and standing crop. In: Fraser J. H. \& J. Corlet. Contributions to Symposium on Zooplankton Production. Rapp. Proc. Verb. Reun. Cons. Perm. int. Explor. Mer. 153: $121-123$.

Heron, A. C. 1972. Population ecology of a colonizing species: the pelagic Tunicate Thalia democratica. I. Individual growth rate and generation time. Oecologia $10(4): 269-293$.

Hidral 1974. Tide tables of the Indonesian Archipelago. Dinas Hidrografi TNI Angkatan Laut Republik Indonesia, Jakarta: 1-425.

Soest, R. W. M. vaN 1973. The genus Thalia Blumenbach, 1798 (Tunicata, Thaliacea), with descriptions of two new species. Beaufortia 20(271): $193-212$.

STRICKLAND, J. D. H. \& T. R. PARSoNS 1968. A practical handbook of seawater analysis. Bull. Fish. Res. Board Canada 167: 1-311.

Tesch, J. J. 1950. The Gymnosomata. Dana Report 36: $1-55$.

WALLACE, A. R. 1962. The Malay Archipelago (republication of the last revised edition of the work first published in 1869 by Macmillan and Company). Dover Publ., New York: XVII + 515 . 